\title{
NOTE
}

\section{In situ submarine pollination in the seagrass Amphibolis antarctica: research notes}

\author{
Jennifer J. Verduin ${ }^{1, *}$, Diana I. Walker ${ }^{1}$, John Kuo ${ }^{2}$ \\ ${ }^{1}$ Department of Botany, University of Western Australia, Nedlands, Western Australia 6907, Australia \\ ${ }^{2}$ Centre for Microscopy and Microanalysis, University of Western Australia, Nedlands, Western Australia 6907 , Australia
}

\begin{abstract}
Field observations, carried out as part of a hydrodynamic study on submarine pollen dispersal in dioecious Amphibolis antarctica (Labill.) Sonder et Aschers. ex Aschers., showed that pollen release and subsequent pollination events occur in stages over a period of approximately $1 \mathrm{mo}$, from late October to early December, at $32^{\circ} 16^{\prime} \mathrm{S}, 115^{\circ}$ $41^{\prime} E$ on the coast of Western Australia. Examination of the female flowers by scanning electron microscopy, during and after pollination events, showed that the filiform pollen had adhered to the stigmas. Our field observations of a subtidal $(2 \mathrm{~m}$ below low water) $A$. antarctica meadow suggest that the pollen sacs dehisce whilst still attached to the male plant. Pollen is released slowly and takes on the approximate density of the seawater, and is then carried by the local coastal currents. No surface agglomerations of pollen were observed. Preliminary qualitative observations from a dye release study at the study site implied that pollen remained within the water column, close to and amongst the canopy, thus enhancing the likelihood of collision with the nearby female plants. This is the first account of in situ pollination of fully submerged subtidal $A$. antarctica.
\end{abstract}

KEY WORDS: Amphibolis antarctica Filiform pollen Pollen release - Hydrophily - Subtidal

Amphibolis antarctica (Labill.) Sonder et Aschers. ex Aschers. is a dioecious seagrass which exhibits viviparity (Kuo \& McComb 1989, Kuo \& Kirkman 1990). This species is widely distributed along the southern and southwestern coast of Australia (Ducker et al. 1977, Kirkman \& Walker 1989, Walker and Cambridge 1995). Adaptation to submarine pollination, or hydrophily, has led to the evolution of specialized features in pollen. Pollen in hydrophilous angiosperms, including $A$. antarctica, is often filiform (e.g. Ducker et al. 1978, McConchie et al. 1982, Pettitt et al. 1983) and has a reduced or no exine layer (e.g. Pettitt et al. 1983). McConchie \& Knox (1989) found that, under controlled

•E-mail:verduin@uniwa.uwa.edu.au conditions, pollen of $A$. antarctica adhered tenaciously to the stigma branches. Cox \& Knox (1988) observed mass pollen release at low tide when the tops of the $A$. antarctica plants were floating on the surface. Their field observations suggested that 2-dimensional pollination may occur. Cox $(1983,1988)$ suggested that filamentous pollen may aggregate at the sea surface to form 'search vehicles' thus increasing the chance of encountering receptive female flowers. Alternatively, the anther may break off and float to the water surface where, in controlled conditions in a seawater aquarium, the submerged lower loculi opened first allowing the pollen to cascade downward (unpubl. results, see McConchie \& Knox 1989). The mechanism of, and adaptations to, submarine pollination in $A$. antarctica in controlled seawater aquarium conditions have been described in detail by Ducker et al. (1978), Pettitt et al. (1983) and McConchie \& Knox (1989) and references therein.

It appears that submarine pollination is exhibited by turtle grass (Thalassia testudinum Banks ex König) in the Caribbean (Cox 1993). A similar submarine pollination mechanism is a feature of the unrelated freshwater species Lepilaena bilocularis Kirk (Cox 1993). Reference to the possibility that Amphibolis antarctica might exhibit submarine pollination is made by a number of authors such as Ducker et al. (1978) and Pettitt et al. (1983). There appear to be no in situ observations of submarine pollination of subtidal $A$. antarctica specimens to date. Many previous studies, such as those described above, were carried out for intertidal A. antarctica populations, where the flowers were floating on the water surface during low tide. Populations of A. antarctica at our study site [Shoalwater Bay, Western Australia (WA)], however, are subtidal and therefore fully submerged at all times (Verduin pers. obs.). An account of our field observations on submarine pollination in $A$. antarctica is presented. 
Materials and methods. Mature male and female plants of Amphibolis antarctica were collected by SCUBA at Shoalwater Bay, WA $\left(32^{\circ} 16^{\prime} \mathrm{S}, 115^{\circ} 41^{\prime} \mathrm{E}\right)$. Progress of development of $A$. antarctica flowers was monitored in situ to estimate timing of the coming pollination event from July 1994 onwards. Collections were carried out on a weekly basis shortly before and after the pollen release, from late October to early December 1994, During pollen release, observations were made approximately every 5th day. Mature female flowers were collected during and after the pollination events. These mature female flowers were fixed in $2.5 \%$ gluteraldehyde, $0.05 \mathrm{M} \mathrm{PO}_{4}$ buffer, $\mathrm{pH} 7$, postfixed with $2 \% \mathrm{OsO}_{4}$, and dried in a critical point drier with $\mathrm{CO}_{2}$. After coating with gold-palladium, specimens were examined with a Philips Stereoscan 505 at $15 \mathrm{kV}$ for scanning electron microscopy (SEM). Field observations documented the method of pollen release and the phasing of the events. To verify the field observations, mature male Amphibolis antarctica plants were collected and replanted in a well-circulated seawater aquarium which was kept at a constant temperature of $21^{n} \mathrm{C}$, inte seawater temperature at the time of collection, and the release of pollen was observed. Dyed seawater was released in situ in and above the canopy of a subtidal A. antarctica meadow. This dye release was filmed with an underwater video camera and observations on dispersal of the dye were made.

Results. Observations showed that the male flowers at the study site were initiated in August, with female flowers lagging 5 to $7 \mathrm{~d}$ behind, and matured in late October. In situ observations showed that pollen sacs dehisced whilst still attached to the plant. The pollen remained within the water column rather than floating to the surface. In some cases pollen became trapped rapidly within the canopy of the same meadow from which it was released.

Sequential pollen release at this site occurred episodically from late October through early December. On further examination of mature male flowers it appeared that after the first pollen release, only $60 \%$ of the male flowers had been released. Large amounts of 'wrack' were apparent after this first event, as leaf clusters of male Amphibolis antarctica were shed after dehiscing of pollen. Over a period of $2 \mathrm{wk}$ following the initial event, further slow pollen release was observed. By then $95 \%$ of all. male plants were spent. During the $2 \mathrm{wk}$ between pollen release events, the $5 \mathrm{~d}$ sampling frequency did not detect any further, shortterm releases. The aquarium experiment verified our field observations in that the pollen sacs dehisced whilst remaining attached to the plant. After slow release and an increase in density, the pollen adhered quickly to the surrounding plants. Due to controlled flow conditions in the tank, dispersal of pollen under these conditions may not be representative of natural conditions

Female flowers from November and December 1994 collections (during and after pollination events) were assumed mature as the stigmas were protruding from the leaf clusters. Detailed SEM examination of female flowers collected on 30 November and 2 December showed that filiform pollen was present on their stigmas. This indicated a potential for fertilisation.

In situ release of dyed seawater within the canopy showed marginal seepage of dyed water from the canopy into the water column above. These preliminary observations would suggest that despite a loss of approximately $30 \%$ to the ambient waters the dye remained within the canopy, which in turn implies that pollination is likely to occur within a meadow. The observations were conducted on a small scale (within $1 \mathrm{~m}^{2}$ frames) and therefore did not allow for an estimate of meadow-to-meadow dispersal.

Discussion and conclusions. Our in situ observations suggest that the subtidal Amphibolis antarctica exhibits 3-dimensional submarine pollination. The pollen, once released, remains within the canopy with a marginal loss to the surrounding water. This is in agreement with the postulation of Cox \& Knox (1988). They suggested that those species not subjected to great tidal ranges remain submerged and may exhibit 3-dimensional submarine pollination.

The question has been raised as to the validity of Amphibolis sp. being fertilised at all. There is some evidence for asexual propagation (Kuo et al. 1987). Little or no genetic variation has been found in AmphiboIis species, as yet, in WA (Waycott et al. 1996). The results reported here, however, provide evidence that pollen reached the stigmas under field conditions. Although this does not prove that fertilisation takes place, there is at least the opportunity for fertilisation. The presence of pollen on the stigmas is the first essential part of pollination.

Les (1988) suggested that the 3-dimensionality of hydrophily leads to high pollen wastage, although higher efficiency may be attained in shallow water where pollen loads may concentrate. Amphibolis antarctica male and female plants occur close together within one meadow (distances between plants may vary between $20 \mathrm{~cm}$ and $5 \mathrm{~m}$ ). It is likely, therefore, that pollen released in this way has a high success rate within one particular meadow. Unlike the 2-dimensional mode of pollination that is exhibited in intertidal A. antarctica as observed by Cox \& Knox (1988) the pollen of subtidal plants does not float to the surface to form rafts. Underwater pollination in some species (e.g. Zostera marina L.) is enhanced by the reduction of water currents over the plant beds and the relatively large area of pollen influence around female flowers 
(Ackerman 1983, 1986). A study to quantify the governing hydrodynamics at the collection site is currently being undertaken.

The phasing of the pollen release can be attributed to female flowers not maturing all at the same time. On any one female plant, both mature and immature flowers occur. However, on examination of the female plants after the final pollen release, i.e. when $95 \%$ of pollen had been released, $98 \%$ of all female flowers were mature. This would in turn maximise the probability of the success of the pollen, and pollination in itself. This possibility is supported by the production of many fruits on a single plant. The study is continuing in order to establish the success rate of the viviparous seedlings.

Acknowledgements. We are indebted to Anne Brearley, Tim Carruthers, Kathryn McMahon and Cameron Sim for their assistance in the field.

\section{LITERATURE CITED}

Ackerman JD (1983) Current flow around Zostera marina plants and flowers: implications for submarine pollination. Biol Bull Mar Biol Lab, Woods Hole 165:504

Ackerman JD (1986) Mechanistic implications for pollination in the marine angiosperm Zostera marina. Aquat Bot 24: $343-353$

Cox PA (1983) Search theory, random motion and the convergent evolution of pollen and pore morphology in aquatic plants. Am Nat 121:9-13

Cox PA (1988) Hydrophilous pollination. A Rev Ecol Syst 19: $261-280$

Cox PA (1993) Water-pollinated plants. Sci Am 269:68-74

Cox PA, Knox RB (1988) Pollination postulates and twodimensional pollination in hydrophilous monocotyledons Ann MO Bot Gard 75:811-818

Ducker SC, Foord NJ, Knox RB (1977) Biology of Australian

This note was submitted to the editor seagrasses: the genus Amphibolis C. Agard (Cymodoceaceae). Aust J Bot 25:67-95

Ducker SC, Pettitt JM, Knox RB (1978) Biology of Australian seagrasses: pollen development and submarine pollination in Amphibolis antarctica and Thalassadendron ciliatum (Cymodoceaceae). Aust J Bot 26:265-285

Kirkman H, Walker DI (1989) Regional studies-Western Australian seagrass. In: Larkum AWD, McComb AJ, Shepherd SA (eds) Biology of seagrasses. A treatise on the biology of seagrasses with special reference to the Australian region. Elsevier, Amsterdam, p 157-180

Kuo J, Cook IH, Kirkman H (1987) Observations of propagation shoots in the seagrass genus Amphibolis C. Agarth (Cymodoceaceae). Aquat Bot 27:291-293

Kuo J, Kirkman H (1990) Anatomy of viviparous seagrasses seedlings of Amphibolis and Thalassodendron and their nutrient supply. Botanica Mar 33:117-126

Kuo J, McComb AJ (1989) Seagrass taxonomy, structure and development. In: Larkum AWD, McComb AJ, Shepherd SA (eds) Biology of seagrasses. A treatise on the biology of seagrasses with special reference to the Australian region. Elsevier, Amsterdam, p 6-56

Les DH (1988) Breeding sytems, population structure, and evolution in hydrophilous angiosperms. Ann MO Bot Gard 75:819-835

McConchie CA, Ducker SC, Knox RB (1982) Biology of Australian seagrasses: floral development and morphology in Amphibolis (Cymodoceaceae). Aust J Bot 30:251-264

McConchie CA, Knox RB (1989) Pollination and reproductive biology of seagrasses. In: Larkum AWD, McComb A.J, Shepherd SA (eds) Biology of seagrasses. A treatise on the biology of seagrasses with special reference to the Australian region. Elsevier, Amsterdam, p 74-111

Pettitt JM, McConchie CA, Ducker SC, Knox RB (1983) Reproduction in seagrasses: pollination in Amphibolis antarctica. Proc R Soc Lond (Ser B) 219:119-135

Walker DI, Cambridge ML (1995) An experimental assessment of the temperature responses of two sympatric seagrasses, Amphibolis antarctica and Amphibolis griffithii, in relation to their biogeography. Hydrobiologia 302:63-70

Waycott M, Walker DI, James SH (1996) Genetic uniformity in a dioecious seagrass, Amphibolis antarctica. Heredity 76 (in press)

Manuscript first received: March 31, 1995

Revised version accepted: October 24, 1995 